\title{
Implementace JIT na expedičních zónách
}

\author{
Pavel Vránek ${ }^{1}$, Michal Šimon ${ }^{1}$ \\ ${ }_{1}$ Západočeská univerzita v Plzni, Fakulta strojní, Katedra průmyslového inženýrství a \\ managementu \\ Univerzitní 8, 306 14, Plzeň, Česká republika \\ vranek@kpv.zcu.cz \\ simon@kpv.zcu.cz
}

\begin{abstract}
Anotace: Článek se zabývá zavedením metody JIT na expedičních zónách $v$ rámci výrobního podniku. Před zavedením metody JIT, byl proveden audit logistických činností a jejich funkčnost. Na základě výsledků auditu, kde došlo k odhalení několika nedostatků, mezi které patrïlo selhávání expedice. Zavedení metody JIT vedlo ke kompletní organizaci a plánování jednotlivých vývozů.
\end{abstract}

\section{1 Úvod}

Práce je zaměřena na sklad výrobní společnosti. $V$ rámci studie je proveden audit logistických činností a jejich funkčnost. Konkrétně se jedná o následující:

- Zmapování současného stavu logistických procesů

- Definování hlavních problémů v oblasti logistických procesů

- Závěrečné zhodnocení

- Návrh postupu + realizace

Hlavní pozornost byla zaměřena na organizaci, príijem materiálu a expedici. Tyto procesy byly detailně zmapovány a překontrolovány (skutečnost/předpoklad), pomocí časových studií a procesní mapy.

Celkové směřování činností, $v$ rámci řešení logistického auditu, bylo nastaveno pro zlepšení využití skladu a přehlednější orientaci k řízení toku materiálu.

\section{Metodika}

$\checkmark$ rámci studie byly použity standardní metody a techniky. Použity byly metody přímého měření - pracovní snímek dne [1], chronometráže, procesní mapy, metoda JIT [2] a 2D a 3D vizualizace pomocí softwaru visTABLE [3].

\section{Analýza současného stavu}

Celý článek je postaven na základě reálného projektu, ve kterém byl proveden logistický audit skladu. $\vee$ rámci projektu byly vypracovány pracovní 
snímky dne, chronometráže, procesní mapa a také datové analýzy. $\mathrm{Na}$ základě výsledků z pozorování a analýz, byly vytvořeny návrhy, které eliminují vypozorované problémy a zvyšují efektivitu práce. Článek je zaměřen pouze na jeden z návrhů, který je ale zásadní pro funkčnost tohoto skladu, a tím jsou expediční zóny a nastavení časových oken.

\subsection{Pracovní snímky dne}

$\mathrm{Na}$ základě pracovních snímků bylo formou analýzy vytvořeno několik výstupních souborů, které udávají časy jednotlivých typư činností pracovníků, dále jakých chyb se během dne pracovníci dopouštějí a veškeré ztrátové činnosti včetně organizačních ztrát. Během pozorování pracovníkư byl kladen též dưraz na hledání veškerých nedostatků na pracovištích, které jakoukoliv formou způsobují snížení efektivity práce.

Níže na obrázku je ukázka z výstupu pracovního snímku dne.

\begin{tabular}{|c|c|c|}
\hline & झ्याms & 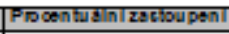 \\
\hline $\begin{array}{l}\text { Ukid a phorave } \\
\text { prasovits }\end{array}$ & 0.0023 & $0,10 \%$ \\
\hline Manlp ulsos BB & $1: 16: 34$ & $19.87 \%$ \\
\hline Pljam BB & $0: 12: 27$ & $3.23 \%$ \\
\hline Pfocklodn ठ̆nl BB & $0: 13: 34$ & $3,52 \mathrm{\%}$ \\
\hline Prasump pfejezd & 0.36 .43 & $9,53 \%$ \\
\hline Kontrola & 0.0404 & $1,06 \%$ \\
\hline 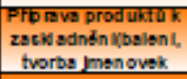 & 0.28 .07 & $7,30 \%$ \\
\hline $\begin{array}{c}\text { Prooovini rozh ovor, } \\
\text { telist on st }\end{array}$ & $0.57: 14$ & $14.85 \%$ \\
\hline 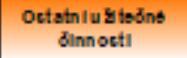 & $0: 14: 59$ & $3.89 \%$ \\
\hline Ztrata onganizadn! & $1: 38: 08$ & $25,47 \%$ \\
\hline Ztrata ocobnl & $0.00: 00$ & $0,00 \%$ \\
\hline Oco bnl potfoby & 0.43 .07 & $11.19 \%$ \\
\hline
\end{tabular}

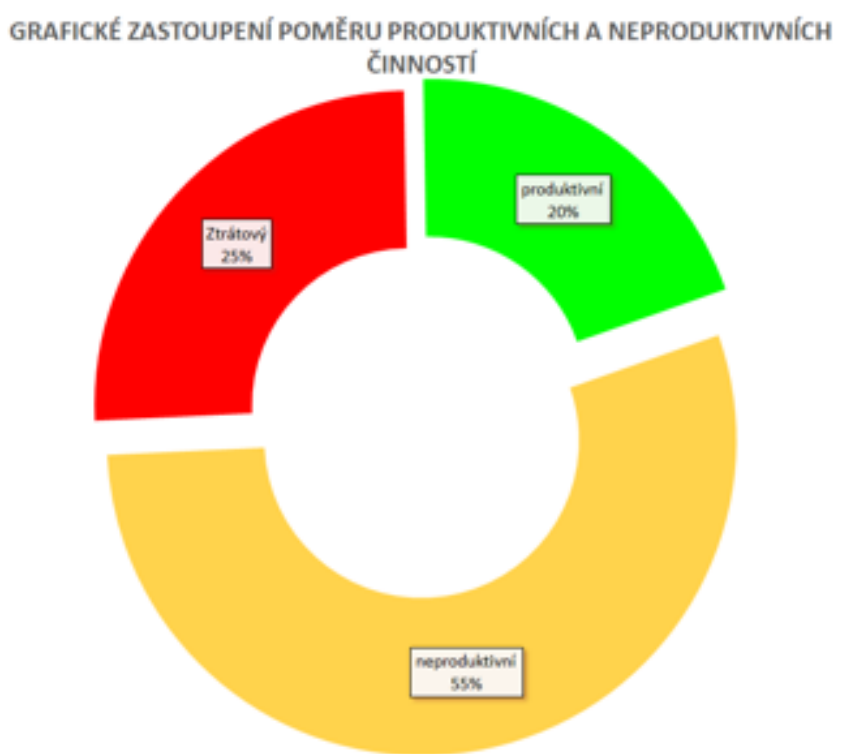

Obrázek 1 - Výstup z měření 


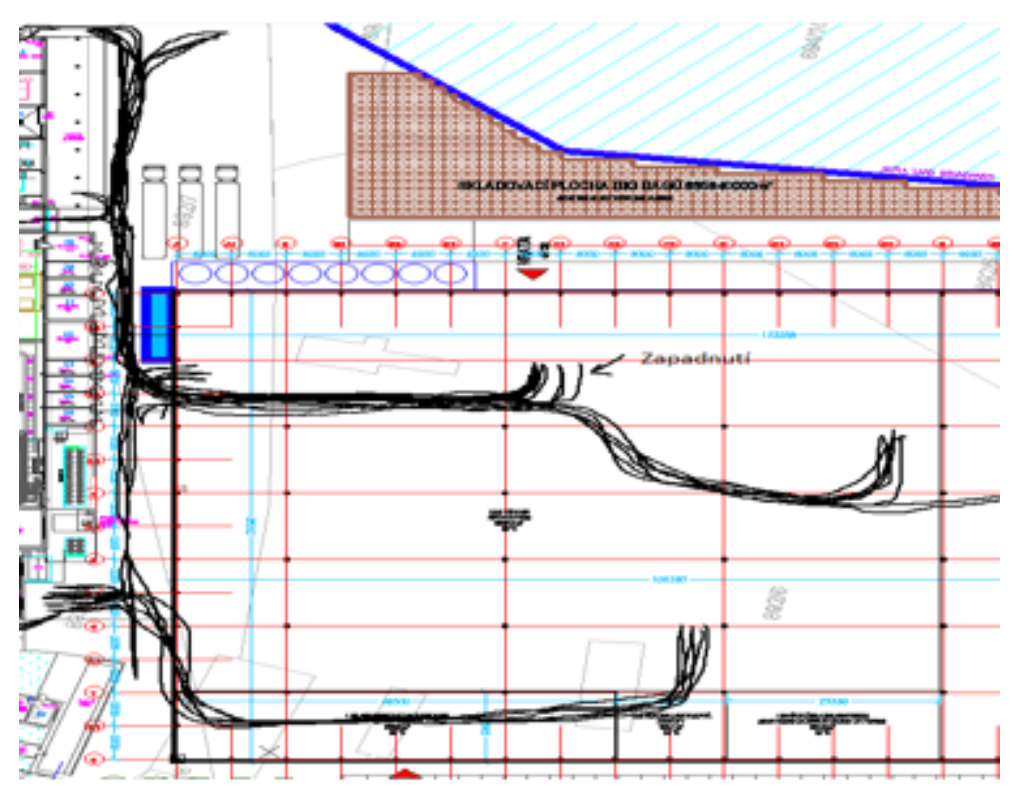

Obrázek 2 - Ukázka výsledků pracovního snímku dne

\subsection{Vypozorované problémy}

Výše zmíněné analýzy, jsem rozdělil na 4 oblasti, ke kterým byly následně přiřazeny odhalené nedostatky.

- Prostorová analýza

- Neexistence expedičních zón

- Časová analýza

- Nakládka - nejsou časová okna

- Dlouhé vychystávací časy

- Potenciál ve využití zaměstnanců

- Datová analýza

- Nevhodné rozložení skladu

- Ležáky

- Procesní analýza

- Systém plánování a neustále změny plánu

- Nedodržování bezpečnosti práce

Dále zde bude popsána část realizace expedičních zón.

\subsection{Expediční zóny}

Cílem této části je nadefinování umístění, počtu a velikosti expedičních zón tak, aby nakládka probíhala systematicky a co nejrychleji. Prostor $v$ blízkosti ramp byl tedy rozdělen do 5 zón. Parametry těchto zón Ize vidět $v$ následující tabulce. 


\begin{tabular}{|l|c|c|c|c|}
\hline Expediční zóny & Šířka [m] & Délka [m] & Plocha [m2] & $\begin{array}{c}\text { Ložná } \\
\text { plocha } \\
\text { (počet pal. } \\
\text { míst) }\end{array}$ \\
\hline Zóna 1 & 5,6 & 6,5 & 36,4 & 28 \\
\hline Zóna 2 & 2 & 6,5 & 13 & 10 \\
\hline Zóna 3 & 2 & 6,5 & 13 & 10 \\
\hline Zóna 4 & 2 & 6,5 & 13 & 10 \\
\hline Zóna 5 & 8,2 & 10 & 82 & 66 \\
\hline
\end{tabular}

Jednotlivé zóny jsou navrženy proto, aby bylo možné vytvořit časová okna na rampách. Dưraz byl kladen na paralelizaci činností nakládky a zrychlení procesu. Na druhé straně minimalizaci ložné plochy těchto zón.

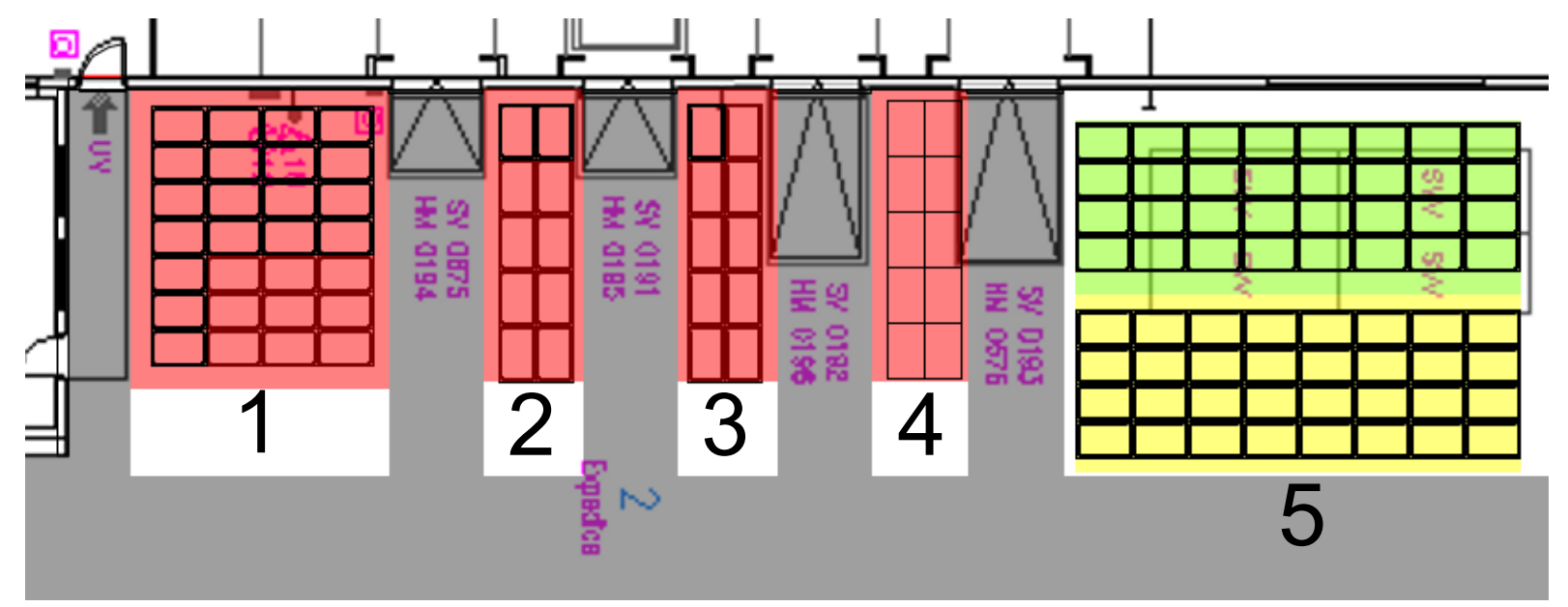

Obrázek 3 - Vizualizace expediční zóny

Zóny 2, 3 a 4 slouží pro prípravu pouze části potřebného objemu, jelikož př́prava zbývajícího množství materiálu může probíhat paralelně s nakládkou. 


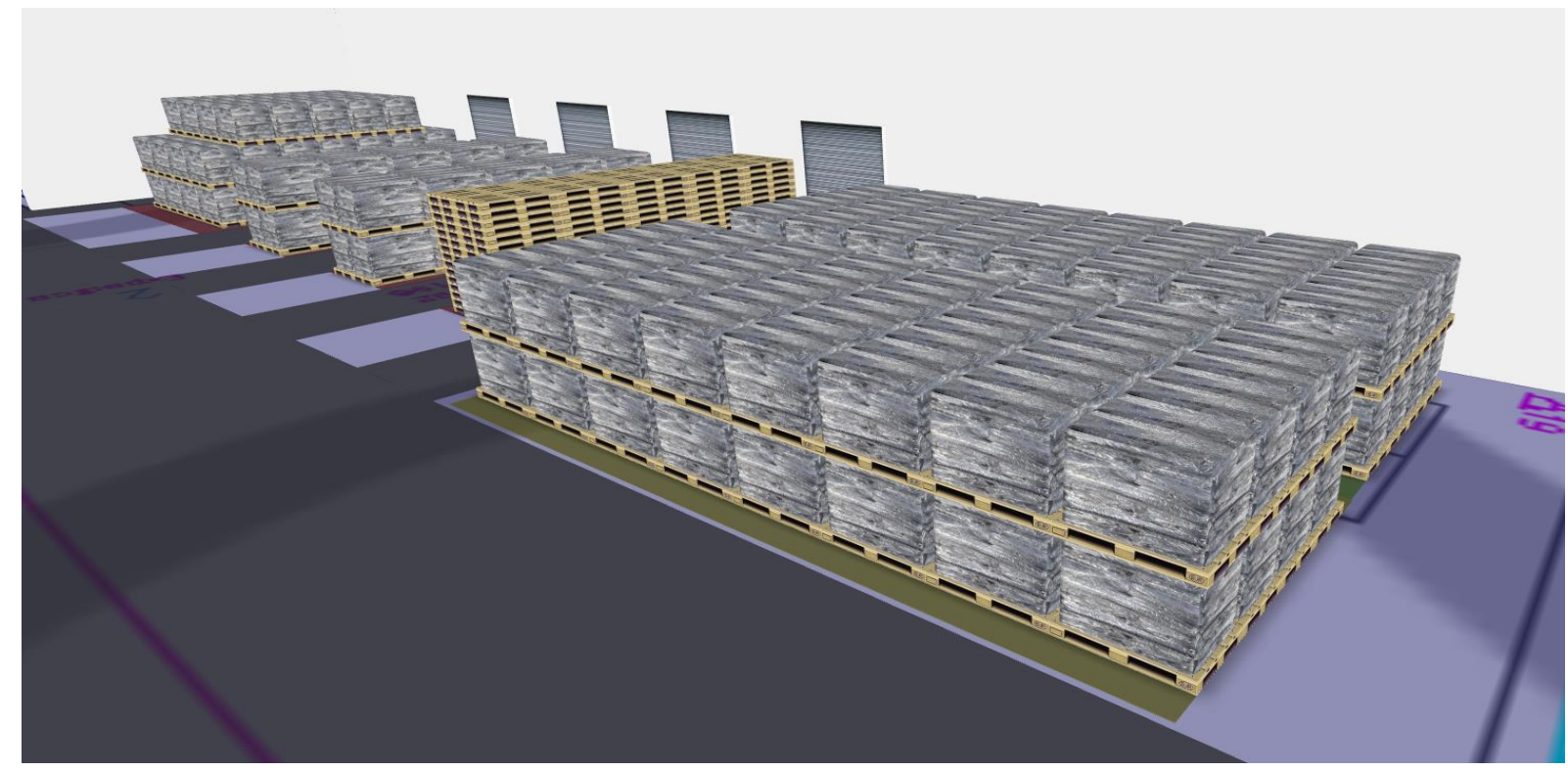

Obrázek 4 - 3D vizualizace

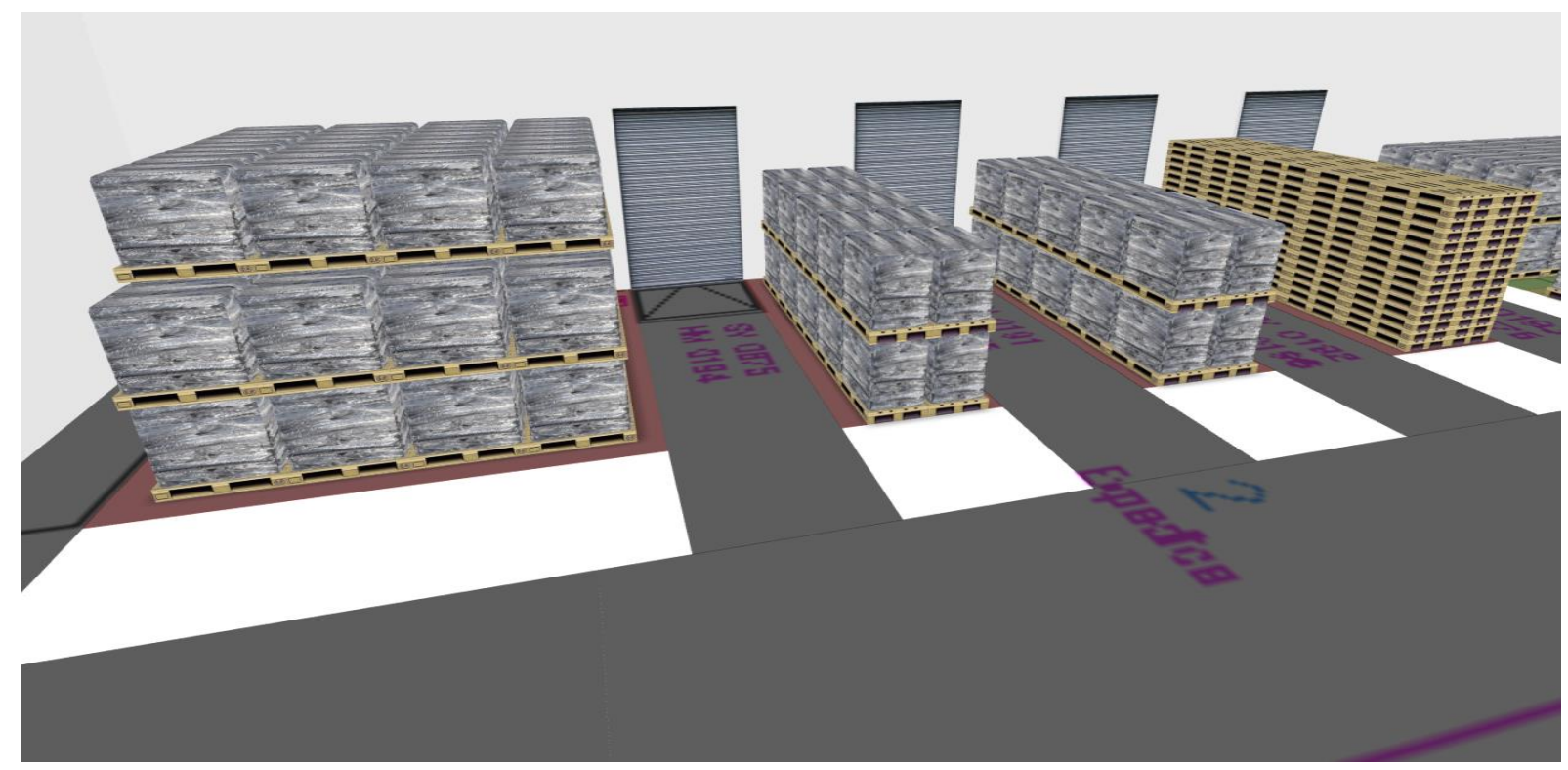

Obrázek 5 - 3D vizualizace

Zóny u čtvrté rampy slouží nejen pro přípravu na nakládku, ale zároveň pro vyskladnění obalů, gitterboxů atd.

\section{Implementace JIT na nakládkových oknech}

Neexistence nakládkových oken způsobuje dlouhé doby nakládky a má negativní vliv na fungování skladu. Ve skladu jsou 4 rampy určené pro nakládku, přičemž 1 je trvale zastavěná a skoro se nepoužívá.

\subsection{Současný stav}

V současném stavu přijíždí na expedici průměrně 35 kamiónů za den. Deset z toho je tvoří většinou vyfouklé lahve pro společnost, která již má vyčleněnou vlastní rampu pro nakládku. Zbytek (tedy 25 kamiónů) přijíždí nahodile a 
nejde tedy připravovat materiál na nakládku předem. To způsobuje vznik front.

\subsection{Předpoklady a pravidla}

Vytvoření systému nakládkových oken předpokládá změnu současných logistických procesů a nastavení nových pravidel.

Předpoklady nakládky:

- Rampa 1

○ PET

○ Expediční zóna na 2 kamióny

- Rampa 2

- Palety + GB

- Expediční zóna na 1 kamión

- Rampa 3

- GB + Oktabíny

- Expediční zóna na 1 kamión

- Rampa 4

- GB + Oktabíny

- Expediční zóna na 1 kamión

- Vyskladňovací zóna na 1 kamión

Pravidla nakládky:

- Rampa 1

○ Zaváží rovnou z výroby

- Manipulant asistuje při nakládce

- Rampa 2

- Vychystána alespoň $1 / 2$

- Manipulant vychystává a asistuje prì nakládce

- Rampa 3

- Vychystána alespoň $1 / 2$

- Manipulant vychystává a asistuje príi nakládce

- $\quad$ Rampa 4

- Vychystávání začíná současně s vykládkou

- Během nakládky manipulant zaváží vyskladněný materiál do skladu 


\subsection{Navrhovaný stav}

Návrh nakládkových oken je rozdělen do 2 fází. Počíá se totiž s tím, že není jednoduché dohodnout výhodné podmínky se všemi dopravci najednou a musí se tedy postupně přecházet na řízený systém nakládek.

\section{Fáze 1}

První fáze předpokládá fixaci 2 ramp. První z nich by byla používána jen pro společnost odvážející PET. Druhá by byla určena pro dalších 10 nakládek. Časy potřebné pro nakládku, včetně rizikové přirážky $20 \%$, jsou zobrazeny níže.

Tabulka 2 - Časy potřebné pro nakládku

\begin{tabular}{|c|c|c|}
\hline \multicolumn{3}{|l|}{ PET } \\
\hline \multicolumn{2}{|l|}{ Před nakládkou } & \multirow{2}{*}{33} \\
\hline Čas prípravy [min] & 33 & \\
\hline \multicolumn{2}{|l|}{ Během nakládky } & \multirow{3}{*}{15} \\
\hline Čas př́ípravy [min] & 0 & \\
\hline Čas nakládky [min] & 15 & \\
\hline \multicolumn{2}{|l|}{ Rizikový př́počet [min] } & 9,6 \\
\hline \multicolumn{2}{|l|}{ Čas celkem [min] } & 57,6 \\
\hline
\end{tabular}

\begin{tabular}{|c|c|c|}
\hline \multicolumn{3}{|l|}{ Palety } \\
\hline \multicolumn{2}{|l|}{ Před nakládkou } & \multirow{2}{*}{33} \\
\hline Čas prípravy [min] & 33 & \\
\hline \multicolumn{2}{|l|}{ Během nakládky } & \multirow{3}{*}{33} \\
\hline Čas prípravy [min] & 33 & \\
\hline Čas nakládky [min] & 30 & \\
\hline \multicolumn{2}{|l|}{ Rizikový prípočet [min] } & 13,2 \\
\hline \multicolumn{2}{|l|}{ Čas celkem [min] } & 79,2 \\
\hline
\end{tabular}

Následující tabulka obsahuje návrh časových oken pro obě rampy. U PET je možné předem připravit více než 2 kamióny prímo u rampy. Další rampa umožňuje prípravu položek pouze pro jeden kamión, proto jsou i posunuty časy nakládek.

Tabulka 3 - Časová okna

\begin{tabular}{|l|r|}
\hline \multicolumn{2}{|c|}{ PET } \\
\hline 1. & $6: 00$ \\
\hline 2. & $7: 00$ \\
\hline 3. & $8: 30$ \\
\hline 4. & $10: 00$ \\
\hline 5. & $11: 30$ \\
\hline 6. & $13: 00$ \\
\hline 7. & $14: 30$ \\
\hline 8. & $16: 00$ \\
\hline 9. & $17: 30$ \\
\hline 10. & $19: 00$ \\
\hline 1. & př́prava \\
\hline 2. & príprava \\
\hline
\end{tabular}

\begin{tabular}{|l|r|}
\hline \multicolumn{2}{|c|}{ GB, PAL } \\
\hline 1. & $6: 00$ \\
\hline 2. & $7: 30$ \\
\hline 3. & $9: 00$ \\
\hline 4. & $10: 30$ \\
\hline 5. & $12: 00$ \\
\hline 6. & $13: 30$ \\
\hline 7. & $15: 00$ \\
\hline 8. & $16: 30$ \\
\hline 9. & $18: 00$ \\
\hline 10. & $19: 30$ \\
\hline 1. & príprava \\
\hline
\end{tabular}

\section{Fáze 2}

Druhá fáze již počíá s nastavením časových oken pro všechny 4 rampy. První a druhá zůstává stejná jako u Fáze 1. Čtvrtá slouží pro vykládku i 
nakládku, protože je zde počíáno nejen s expediční zónou ale i s vykládkovým prostorem.

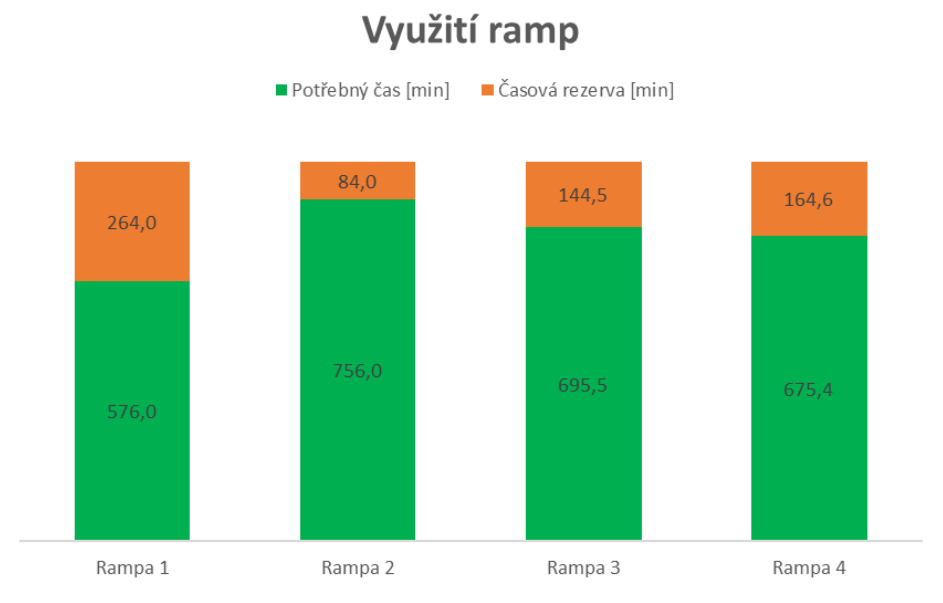

Obrázek 6 - Využití ramp

Využití časového fondu jednotlivých nakládkových ramp je vidět na grafu výše.

\section{Závěr}

$\checkmark$ rámci toho článku byl představen projekt s názvem audit logistických činností. Cílem tohoto projektu bylo zmapovat celý současný stav skladu společnosti a navrhnout nápravná opatření. $V$ článku je popsán zásadní problém skladu - neexistence expedičních zón a chaos na rampách.

Návrh obsahoval dvě části:

- Vytvoření expedičních zón,

- nastavení časových oken.

Návrh expedičních zón obsahuje vytvoření 5 zón, které slouží pro prípravu materiálu a zároveň pro vykládku kamionu. Tímto krokem došlo k zefektivnění práce skladníků a zároveň organizovanému chodu expedice. Po zavedení časových oken na dvou rampách, se proces vývozu zharmonizoval a nyní nedochází k dlouhému čekání kamionů na odbavení, blokování príjjezdové komunikace, a dalším podobným situacím, které byly způsobeny neorganizovaným prríjezdem kamionů. Společnost čeká ještě běh na delší trat', nebot' zbývá domluvit ještě polovinu dopravců a nastavení zbylých časových oken.

\section{Poděkování}

Tento článek byl vytvořen za podpory interního grantu Západočeské univerzity v Plzni číslo SGS-2018-031 s názvem Optimalizace parametrů udržitelného výrobního systému. 


\section{Použitá literatura}

[1] Vltavský, M., Jizba, J., Kolář, J. Racionalizace a normování práce. 1. vyd., Trutnov: Dům kultury ROH Trutnov, 1987.

[2] Gregor, M., Košturiak, J. Just-in-time. Výrobná filozofia pre dobrý management. 1. vyd. Bratislava: ELITA, 1994. 299 s. ISBN 80-85323-64-8,

[3] Miller, A., Bureš, M., Kurkin, O., Pešl, J. ZIVDIG : Projektování výrobní základy - praktická část, e-book, Smartmotion, 2013. ISBN 978-80-8753931-6. 